\title{
Emendation of the Genus Issatchenkia Kudriavzev and Comparison of Species by Deoxyribonucleic Acid Reassociation, Mating Reaction, and Ascospore Ultrastructure
}

\author{
C. P. KURTZMAN, M. J. SMILEY, AND C. J. JOHNSON \\ Northern Regional Research Center, Agricultural Research, Science and Education Administration, U.S. \\ Department of Agriculture, Peoria, Illinois 61604
}

\begin{abstract}
The genus Issatchenkia Kudriavzev has been emended to include all nitratenegative, multilateral budding yeast species that form unconjugated persistent asci with roughened spheroidal ascospores and have Q-7 ubiquinone in the electron transport system. Pichia kudriavzevii (Issatchenkia orientalis), Pichia terricola, Pichia scutulata var. scutulata, and Pichia scutulata var. exigua are assigned to this genus as Issatchenkia orientalis Kudriavzev, Issatchenkia terricola (van der Walt) comb. nov., Issatchenkia scutulata var. scutulata (Phaff et al.) comb. nov., and Issatchenkia scutulata var. exigua (Phaff et al.) comb. nov., respectively. Additionally, one new species, Issatchenkia occidentalis, is described. The type strain of $I$. occidentalis is NRRL Y-7552 (=CBS 5459). Electron microscopy demonstrated that the ascospore walls of $I$. terricola have thick inner and outer layers and that the ascospores of the other species have walls with a thick inner layer and a thin, dense outer layer. With the exception of $I$. scutulata var. scutulata, ascospore surface ornamentation arises from the dense outer layer. Deoxyribonucleic acid reassociation studies and mating tests confirmed the recognition of four species in the genus Issatchenkia and showed Candida krusei to be the imperfect state of $I$. orientalis; Candida sorbosa was identified as the imperfect form of $I$. occidentalis. I. scutulata var. scutulata and I. scutulata var. exigua showed only $25 \%$ deoxyribonucleic acid complementarity, yet intervarietal matings formed viable ascospores. This is the lowest deoxyribonucleic acid relatedness ever shown between strains capable of genetic hybridization, and the implications of this finding are discussed.
\end{abstract}

The genus Issatchenkia was described by $\mathrm{Ku}$ driavzev (11) in 1960 for yeasts which were isolated from fruit juices and berries and which had unconjugated asci and spheroidal ascospores. The single species originally included in the genus, Issatchenkia orientalis Kudriavzev, was transferred to Pichia by Kreger-van Rij (N. J. W. Kreger-van Rij, Ph.D. thesis, University of Leiden, Leiden, The Netherlands, 1964) as Pichia orientalis (Kudriavzev) Kreger-van Rij; however, Boidin et al. (3) noted that the specific epithet orientalis had been used previously in the name of another Pichia species, and therefore, they proposed the name Pichia kudriavzevii Boidin, Pignal et Besson.

Pichia terricola van der Walt and Pichia scutulata Phaff, Miller et Miranda are two other taxa phenotypically similar to $P$. kudriavzevii. Scanning electron microscopy has shown that all three have warty ascospore walls $(14,23)$, and in this respect, they differ from other roundspored species of Pichia, which have essentially smooth spore walls. Although these three spe- cies are similar in ascospore surface structure to species of Torulaspora (van der Walt [31] group III, Saccharomyces species) and Debaryomyces (17), they do not form the asci with tapered projections that are associated with Torulaspora or exhibit the mother-daughter conjugation typical of Debaryomyces. Consequently, when ascus morphology and ascospore ultrastructure are considered, these species appear to represent a natural grouping that is different from other yeast genera, and we propose to place them in the genus Issatchenkia. On the basis of deoxyribonucleic acid (DNA) base sequence complementarity, mating reaction, and ascospore ultrastructure, we describe one new species, and several suggested perfect-imperfect relationships are verified. Additionally, our multifaceted approach allowed an examination of species parameters that heretofore was not possible and suggested that, as is the case among some higher eucaryotes, the boundaries of individual yeast species may be less precisely definable than previously supposed. 


\section{MATERIALS AND METHODS}

Yeast strains. Cultures of the strains studied are maintained in the Agricultural Research Culture Collection, Northern Regional Research Center, and their designations and salient characteristics are shown in Table 1.

Physiological and morphological characterization. The methods used for determining morphology and performing the fermentation and assimilation tests have been described previously (34).

DNA purification, base composition determination, and reannealing reactions. Extraction and purification of DNA was accomplished by a combination of the procedures of Marmur (18) and Bernardi et al. (2) as described by Price et al. (24). The DNA was considered to be of sufficient purity if it deviated no more than 0.05 from the following ratios: absorbance at $260 \mathrm{~nm} /$ absorbance at $280 \mathrm{~nm}=1.86$ and absorbance at $230 \mathrm{~nm} /$ absorbance at $260 \mathrm{~nm}=0.5$ (19). The quality of the DNA was also assessed from analytical ultracentrifuge scans and from thermal melting profiles.

The guanine plus cytosine content of nuclear DNA was calculated from buoyant density values in cesium chloride $(25,29)$ and was based on three or four separate determinations made with a Spinco model $\mathbf{E}$ analytical ultracentrifuge equipped with an electronic scanner. Micrococcus lysodeikticus DNA was used as a reference; this DNA had a buoyant density of 1.7311 $\mathrm{g} / \mathrm{ml}$ when compared with DNA from Escherichia coli $\mathrm{K}-12$, the density of which was taken to be 1.7100 $\mathrm{g} / \mathrm{ml}(25)$.

The extent of DNA reassociation was determined spectrophotometrically by using essentially the method reported by Seidler and Mandel (27) and Seidler et al. (26), as described by Kurtzman et al. (C. P. Kurtzman, M. J. Smiley, C. J. Johnson, L. J. Wickerham, and G. B. Fuson, Int. J. Syst. Bacteriol., in press).

Mating studies. The procedures used for mating tests with the new species and $P$. terricola have been described previously (15). For $P$. scutulata var. scutulata and $P$. scutulata var. exigua, ability to mate and to sporulate was tested on YM agar (34) at $25^{\circ} \mathrm{C}$. Single-ascospore isolates were obtained by micromanipulation. Before micromanipulation, asci were digested with the enzyme preparation glusulase (Endo Laboratories, Inc., Garden City, N.Y.).

Electron microscopy. Ascospores were critical point dried before viewing by scanning electron microscopy, as described previously (12). The preparations were examined with a Cambridge Stereoscan Mark II scanning electron microscope at an accelerating voltage of $20 \mathrm{kV}$

Asci to be examined by transmission electron microscopy were fixed in $1.5 \%$ potassium permanganate for $2 \mathrm{~h}$, followed by postfixation for $2 \mathrm{~h}$ in $1 \%$ osmium tetroxide in $0.1 \mathrm{M}$ cacodylate buffer. The fixed material was suspended in $2 \%$ water agar for ease of handling and dehydrated through a graded ethanol series. Fixation and dehydration were carried out at $5^{\circ} \mathrm{C}$. After dehydration, the material was embedded in Spurr epoxy resin (Polysciences, Inc., Warrington, Pa.) and thin sectioned with a diamond knife. Thin sections were stained for $2 \mathrm{~h}$ in $0.5 \%$ uranyl acetate (in ethanol-methanol, $7: 3$ ); this was followed by staining in a $2.6 \%$ lead citrate solution for $8 \mathrm{~min}$. The preparations were examined with a Hitachi 500 transmission electron microscope.

\section{RESULTS}

Species of Pichia that we propose to transfer to Issatchenkia form roughened, spheroidal ascospores in unconjugated, persistent asci and have Q-7 ubiquinone in the electron transport system. Those round-spored species still retained in Pichia have ascospores that are smooth. Their asci either are dehiscent or show mother-daughter conjugation, or they have both of these characteristics. Additionally, they form Q-9 ubiquinone. Mating reaction and extent of DNA relatedness were used to separate species assigned to Issatchenkia. As Table 1 shows, the species can be separated conveniently on the basis of carbon assimilation reactions. Diploid species of Saccharomyces, which produce smooth ascospores in unconjugated asci and have Q-6 ubiquinone, may appear similar to species of Issatchenkia when viewed by light microscopy. The early formation of pellicles in liquid media by Issatchenkia spp. distinguishes between these two genera.

Ascospore ultrastructure is an important criterion in the emended description of Issatchenkia, but spores from $I$. orientalis, the type species, have been poorly characterized. However, we felt that emendation of the description of this genus was reasonable on the basis of our more thorough examination of the spores of the other species which we assign to this genus.

Description of taxa. Kudriavzev (11) provided the following description of Issatchenkia.

Cells are ellipsoidal to elongate, 2.7 to 6 by 3.5 to $13.5 \mu \mathrm{m}$ or longer. Spores are round with a smooth wall; one spore is formed per ascus. The spores germinate to produce vegetative cells without conjugation. Glucose is fermented. Glucose, sucrose, ethanol, glycerol, lactic acid, succinic acid, and citric acid are assimilated. Nitrate is not assimilated. A pellicle may be formed in liquid media.

To accommodate additional species, we propose to emend the description of the genus Issatchenkia as follows:

Asexual reproduction is by multilateral budding on a narrow base. Cells are spheroidal, ellipsoidal, or elongate, and pseudohyphae are present. Asci are unconjugated or are conjugated if formed by the pairing of complementary mating types. Asci are persistent and contain one to four roughened spheroidal ascospores. The protuberances causing the ascospores to appear 


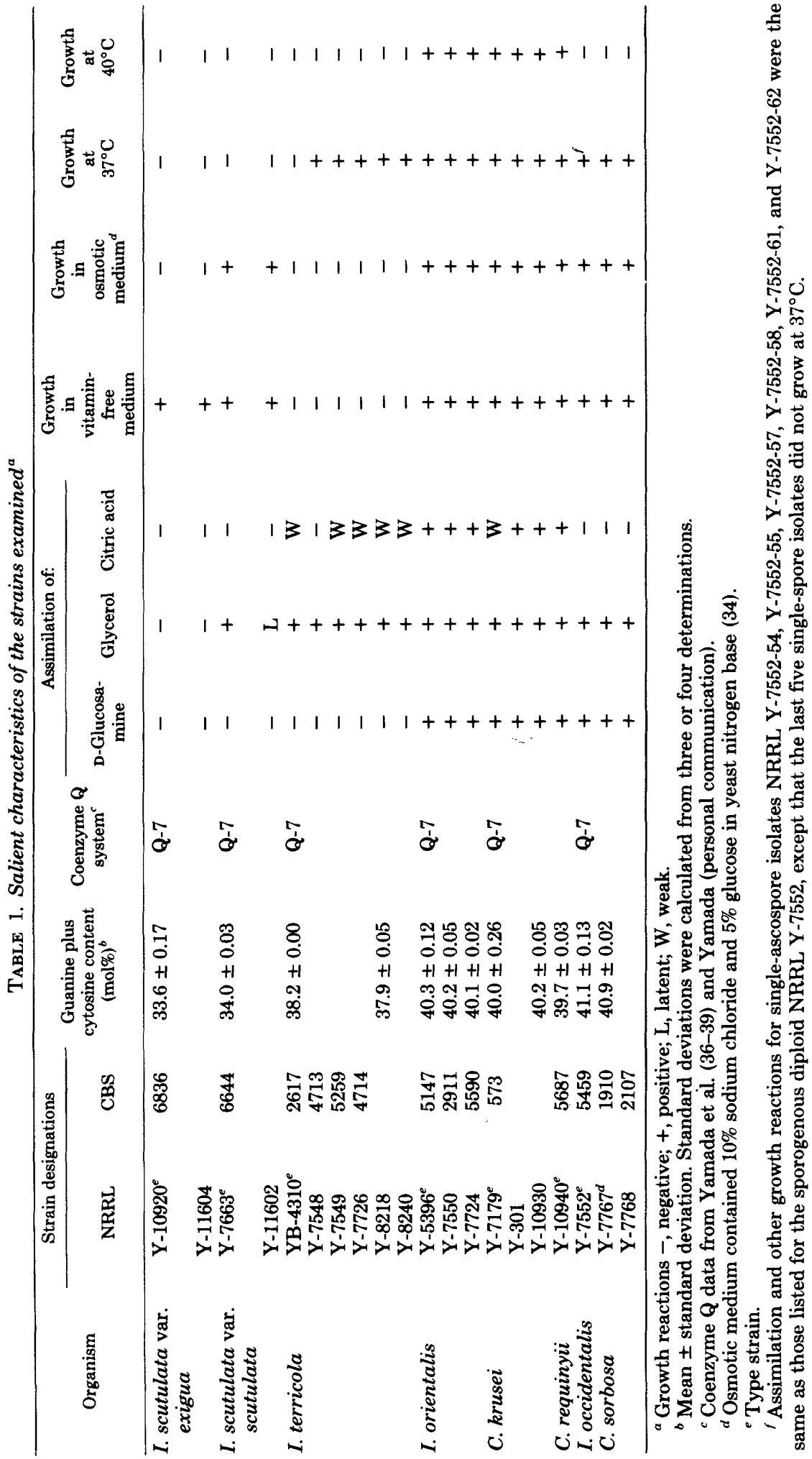


roughened may not be visible under light microscopy. Sugars may be fermented, but nitrate is not assimilated. Q-7 ubiquinone is present in the electron transport system.

Species accepted in the genus Issatchenkia (i) Issatchenkia occidentalis sp. nov. (Synonym: Candida sorbosa Hedrick et Burke ex van Uden et Buckley 1970 [32].)

Etymology: The species epithet of $I$. occidentalis refers to the collection site, which was located in the western hemisphere.

(a) Latin diagnosis of I. occidentalis sp. nov. Species heterothallica. Asci persistentes, 1 vel 2 ascosporos spheroidales asperos habentes, 2.9$4.1 \mu \mathrm{m}$ diametro. Asci liberi. In agare maltoso cellulae singulae aut in binae, ellipsoidales-elongatae, 2-5 × 4-21 $\mu \mathrm{m}$. Pseudohyphae copiosae; hyphae verae desunt. In agare morphologico incrementum eburneum, umidum, subnitidum, butyraceum; margo fimbriata pseudohyphis.

Glucosum acriter fermetatur; galactosum, maltosum, sucrosum, lactosum, raffinosum, et trehalosum non fermentantur.

Glucosum, L-sorbosum (positivum, latens, negativum), D-glucosaminum $\cdot \mathrm{HCl}$ (positivum, imbecillum), ethanolum, glycerolum (positivum, imbecillum), DL-acidum lacticum (positivum, imbecillum), et acidum succinicum assimilantur. Non assimilantur galactosum, maltosum, sucrosum, cellobiosum, trehalosum, lactosum, melibiosum, raffinosum, melezitosum, inulinum, amylum solubile, D-xylosum, L-arabinosum, Darabinosum, D-ribosum, L-rhamnosum, i-erythritolum, ribitolum, galactitolum, D-mannitolum, glucitolum, $\alpha$-methyl-D-glucosidum, salicinum, potassii D-gluconas, calcii 2-keto-D-gluconas, potassii 5-keto-D-gluconas, saccharas potassii-sodii, acidum citricum, ethyl-acetoacetas, inositolum, et nitras potassii. Augmentum copiosum in temperatura $37^{\circ} \mathrm{C}$, et si vitamina adsint in medio. Amylum non fit; esteres non fiunt; gelatinum non liquescit.

Typus: NRRL Y-7552 (=CBS 5459) designat stirpem typicam. Typi conjungentes complementarii: NRRL Y-7552-61 et NRRL 7552-62. Culturae servantur in Collectione Culturarum, Officina Investigationum Tractus Borealis, Peoria, Ill.

(b) Description of I. occidentalis sp. nov. Growth on malt extract agar: After 3 days at $25^{\circ} \mathrm{C}$, the cells are ovoidal to elongate, 2.2 to 4.3 by 3.2 to $9.3 \mu \mathrm{m}$, and single or in pairs. Growth is butyrous and light cream colored.

Dalmau plate culture on morphology agar: After 7 days at $25^{\circ} \mathrm{C}$, growth under a cover glass shows abundant and moderately well-branched pseudohyphae. Aerobic growth is white to tannish white, dull, butyrous, striated, and slightly raised with a flattened center. Margins are en- tire, finely serrate, or have small lobes. Colonies are fringed with pseudohyphae.

Formation of ascospores: Diploid cultures form ascospores on sterilized cucumber wedges and less frequently on carrot wedges. Sporulation is sparse and may require several weeks at $25^{\circ} \mathrm{C}$. One or two spheroidal ascospores $(2.9$ to $4.1 \mu \mathrm{m}$ ) are formed in each persistent unconjugated ascus. Asci are free or ascospores are formed within pseudohyphal cells. Previously we showed this species to be heterothallic by isolation of single ascospores (15). After conjugation of complementary mating types, zygotes usually give rise to a succession of diploid cells that sporulate; consequently, conjugated asci are rarely, if ever, observed. Complementary mating types from the type strain are NRRL Y-7552-61 and NRRL Y-7552-62. The type strain of Candida sorbosa, NRRL Y-7767, conjugated with NRRL Y-7552-62 and formed ascospores, thus confirming this species as the imperfect form of I. occidentalis (15).

Fermentation: Glucose is strongly fermented. There is no fermentation of galactose, maltose, sucrose, lactose, raffinose, or trehalose.

Carbon compounds assimilated: Glucose, Lsorbose (positive, latent, negative), D-glucosamine. $\mathrm{HCl}$ (positive or weak), ethanol, glycerol (positive or weak), DL-lactic acid (positive or weak), and succinic acid are assimilated.

Carbon compounds not assimilated: Galactose, maltose, sucrose, cellobiose, trehalose, lactose, melibiose, raffinose, melezitose, inulin, soluble starch, D-xylose, L-arabinose, D-arabinose, D-ribose, L-rhamnose, $i$-erythritol, ribitol, galactitol, D-mannitol, glucitol, $\alpha$-methyl-D-glucoside, salicin, potassium D-gluconate, calcium 2keto-D-gluconate, potassium 5-keto-D-gluconate, potassium sodium saccharate, citric acid, ethyl acetoacetate, and inositol are not assimilated.

Assimilation of potassium nitrate: Negative.

Growth in vitamin-free medium: Positive.

Growth in $10 \%$ sodium chloride plus $5 \%$ glucose in yeast nitrogen base: Positive.

Growth at $37^{\circ} \mathrm{C}$ : Positive.

Growth at $40^{\circ} \mathrm{C}$ : Negative.

Starch formation: Negative.

Production of esters: Negative.

Liquefaction of gelatin: Negative.

Guanine plus cytosine content of nuclear DNA: 40.9 to $41.1 \mathrm{~mol} \%$ (range of two strains [Table 1]).

Type: The type strain, NRRL Y-7552 (=CBS 5459 ), was received from $H$. J. Phaff, but the substrate from which it was isolated is unknown.

(ii) Issatchenkia orientalis Kudriavzev 1960 (11). (Synonyms: Pichia orientalis $[\mathrm{Ku}-$ driavzev] Kreger-van Rij 1964 [Kreger-van Rij, 
Ph.D. thesis]; Pichia kudriavzevii Boidin, Pignal et Besson 1965 [3]; Candida krusei [Cast.] Berkhout 1923, and the synonyms of this taxon given by van Uden and Buckley [32]; Candida requinyii Szép et Novák 1963 [28]).

(iii) Issatchenkia scutulata (Phaff, Miller et Miranda 1976) comb. nov. Issatchenkia scutulata (Phaff, Miller et Miranda 1976) comb. nov. var. scutulata (Phaff, Miller et Miranda 1976) comb. nov. (Basionym: Pichia scutulata Phaff, Miller et Miranda 1976 var. scutulata Phaff, Miller et Miranda 1976 [23].)

Issatchenkia scutulata (Phaff, Miller et Miranda 1976) comb. nov. var. exigua (Phaff, Miller et Miranda 1976) comb. nov. (Basionym: Pichia scutulata Phaff, Miller et Miranda 1976 var. exigua Phaff, Miller et Miranda 1976 [23].)

(iv) Issatchenkia terricola (van der Walt 1957) comb. nov. (Basionym: Pichia terricola van der Walt 1957 [30]. Synonym: Saccharomyces terricolus [van der Walt] Novák et Zsolt 1961 [22].)

DNA reassociation studies. Of the four extant strains labeled $P$. kudriavzevii, the three now assigned to $I$. orientalis showed 93 to $100 \%$ base sequence complementarity (Table 2 ). The fourth strain, NRRL Y-7552, differed from the other three by its inability to assimilate citric acid and by its failure to grow at $40^{\circ} \mathrm{C}$. This strain, the type strain of $I$. occidentalis, showed low ( 3 to $8 \%$ ) sequence relatedness to the three strains of $I$. orientalis. The extent of reassociation between $I$. orientalis and its suspected imperfect forms, C. krusei and C. requinyii, was 97\% or greater. Similarly, C. sorbosa showed $98 \%$ relatedness to $I$. occidentalis but low complementarity with $I$. orientalis. Pairwise com- parisons among all Issatchenkia species showed only low (0 to $8 \%$ ) levels of reassociation (Table 2 ), thus confirming the division of the genus into four species.

The extent of complementarity between the two varieties of $I$. scutulata was surprisingly low, averaging only $24 \%$ (Table 3 ). The presence of rapidly renaturing sequences in our DNA preparations did not seem to be responsible for the limited sequence relatedness shown. By analysis of early data points in a second-order rate plot calculated by the method of Wetmur and Davidson (33) (data not shown), we estimated that our DNA preparations contained no more than 5 to $10 \%$ rapidly renaturing sequences; consequently, differences between the varieties appear to reside primarily in the unique sequences. Phenotypically, I. scutulata var. scutulata can be separated from I. scutulata var. exigua by its growth in glycerol and osmotic media (Table 1).

Mating studies. We were unable to induce sporulation in the three known strains of $I$. orientalis, and mixtures between pairs of them or with cultures of $C$. krusei failed to elicit mating or sporulation. Previously, we showed $I$. occidentalis and $I$. terricola to be heterothallic through single-ascospore isolations (15). This same technique allowed demonstration of heterothallism in both varieties of $I$. scutulata.

Pairing of mating types in all possible combinations failed to show any mating response among I. occidentalis, I. scutulata, and I. terricola. Previously, we noted extremely infrequent conjugations between $I$. occidentalis NRRL Y7552-62 and two strains of $I$. orientalis (NRRL Y-5396 and NRRL Y-7550), but ascospores were never formed (15). In that study, mating tests

TABLE 2. Extent of DNA reassociation between species of Issatchenkia and their imperfect forms in the genus Candida

\begin{tabular}{|c|c|c|c|c|}
\hline \multirow[b]{2}{*}{ Organism $^{a}$} & \multicolumn{4}{|c|}{ \% DNA reassociation with: } \\
\hline & $\begin{array}{l}\text { I. orientalis } \\
\mathrm{Y}-5396^{b}\end{array}$ & $\begin{array}{c}\text { I. occidentalis } \\
\mathrm{Y}-7552^{b}\end{array}$ & $\begin{array}{l}\text { I. terricola } \\
\text { YB- } 4310^{b}\end{array}$ & $\begin{array}{l}\text { C. krusei } \\
\text { Y. } 7179^{b}\end{array}$ \\
\hline I. orientalis $\mathrm{Y}-7550$ & $93 \pm 1.6^{c}$ & $8 \pm 3.8$ & & \\
\hline I. orientalis $\mathrm{Y}-7724$ & $100 \pm 2.0$ & $5 \pm 3.9$ & & \\
\hline I. occidentalis $\mathrm{Y}-7552^{b}$ & $3 \pm 0.7$ & & & \\
\hline I. terricola YB-4310 & $5 \pm 3.4$ & $3 \pm 4.6$ & & \\
\hline I. terricola Y-8218 & & & $92 \pm 0.2$ & \\
\hline C. krusei Y $-7179^{b}$ & $99 \pm 1.2$ & $8 \pm 5.3$ & & \\
\hline C. krusei $\mathrm{Y}-10,930$ & & & & $99 \pm 1.4$ \\
\hline C. requinyii $\mathrm{Y}-10,940^{b}$ & $97 \pm 4.4$ & & & $96 \pm 2.8$ \\
\hline C. sorbosa Y $-7767^{b}$ & $4 \pm 4.9$ & $98 \pm 2.5$ & & $1 \pm 3.0$ \\
\hline I. scutulata var. scutulata $\mathrm{Y}-7663^{b}$ & $5 \pm 0.7$ & $2 \pm 3.5$ & $4 \pm 0.6$ & \\
\hline I. scutulata var. exigua $\mathrm{Y}-10,920^{b}$ & $4 \pm 1.1$ & $3 \pm 1.0$ & $0 \pm 1.1$ & \\
\hline
\end{tabular}

\footnotetext{
${ }^{a}$ Strain numbers are Northern Regional Research Center designations.

b Type strain.

${ }^{c}$ Mean \pm standard deviation. Standard deviations were calculated from three determinations.
} 
TABLE 3. Extent of DNA reassociation between strains of I. scutulata var. scutulata and I. scutulata var. exigua

\begin{tabular}{|c|c|c|c|}
\hline \multirow[b]{2}{*}{ Organism $^{a}$} & \multicolumn{3}{|c|}{ \% DNA reassociation with: } \\
\hline & $\begin{array}{l}\text { I. scutulata } \\
\text { var. scutulata } \\
{\text { Y }-7663^{b}}^{b}\end{array}$ & $\begin{array}{l}\text { I. scutulata } \\
\text { var. exigua } \\
\text { Y-10, } 920^{b}\end{array}$ & $\begin{array}{c}\text { I. scutulata } \\
\text { var. exigua } \\
\text { Y-11, 604 }\end{array}$ \\
\hline I. scutulata var. scutulata Y-11, 602 & $100 \pm 1.0^{c}$ & $23 \pm 0.6$ & $26 \pm 1.7$ \\
\hline 1. scutulata var. exigua $\mathrm{Y}-10,920^{b}$ & $21 \pm 3.1$ & & \\
\hline I. scutulata var. exigua $\mathrm{Y}-11,604$ & $24 \pm 1.8$ & $92 \pm 1.3$ & \\
\hline I. orientalis Y-5396 $6^{b}$ & $5 \pm 0.7$ & $4 \pm 1.1$ & \\
\hline I. occidentalis $\mathrm{Y}-7552^{b}$ & $2 \pm 3.5$ & $3 \pm 1.0$ & \\
\hline I. terricola $\mathrm{YB}-4310^{b}$ & $4 \pm 0.6$ & $0 \pm 1.1$ & \\
\hline
\end{tabular}

${ }^{a}$ Strain numbers are Northern Regional Research Center designations.

${ }^{b}$ Type strain.

'Mean \pm standard deviation. Standard deviations were calculated from three determinations.

showed $C$. sorbosa to be the imperfect state of I. occidentalis, and this was confirmed in this work by DNA reassociation.

Despite the rather limited extent of DNA complementarity between I. scutulata var. scutulata and $I$. scutulata var. exigua, intervarietal crosses gave 3 to $6 \%$ viable ascospores (Table 4). Matings between single-ascospore cultures derived from these intervarietal crosses produced ascospores showing increased viability compared with the initial pairings. Progeny from intervarietal crosses were able to form ascospores when backcrossed to parental strains.

Ascospore ultrastructure. Scanning electron microscopy showed that the ascospores of I. occidentalis, I. terricola, and the two varieties of $I$. scutulata were uniformly covered with protuberances (Fig. 1, 3, 5, and 7). These outgrowths appeared to be similar in all species, but they were much larger on ascospores of $I$. terricola and could be perceived as roughness under light microscopy.

When ultrathin sections of the spores were examined by transmission electron microscopy, differences in spore wall composition were evident among the species (Fig. 2, 4, 6, and 8 through 12).I. occidentalis and the two varieties of I. scutulata seem to have the same basic spore wall composition, i.e., a thick, electron-light inner layer that becomes progressively denser toward the surface and a thin, electron-dense outer layer. Protuberances on spores of $I$. occidentalis and I. scutulata var. exigua seem to arise from the thin outer layer, whereas those from spores of I. scutulata var. scutulata originate from the thick inner layer.
TABLE 4. Ascospore viability of intra- and intervarietal crosses of I. scutulata var. scutulata NRRL Y.7663 and I. scutulata var. exigua NRRL $Y \cdot 10,920$

\begin{tabular}{lcl}
\hline \multicolumn{1}{c}{ NRRL no. of parent } & & $\begin{array}{c}\text { No. of ascospores via- } \\
\text { ble/total no. of asco- } \\
\text { spores isolated }\end{array}$ \\
\hline Y-7663 & $23 / 23 \quad(100)^{c}$ \\
Y-7663-2 $\times$ Y-7663-3 & $41 / 68 \quad(60)$ \\
Y-10,920 & $8 / 36 \quad(22)$ \\
Y-10,920-3 $\times$ Y-10,920-4 & $38 / 46 \quad(83)$ \\
Y-7663-2 $\times$ Y-10,920-3 & $5 / 85 \quad(6)$ \\
Y-7663-3 $\times$ Y-10,920-4 & $3 / 102(3)$ \\
$(Y-7663-2 \times$ Y-10,920-3)-1 $\times(Y-$ & $9 / 53 \quad(17)$ \\
$7663-3 \times$ Y-10,920-4)-1 & & \\
\hline
\end{tabular}

${ }^{a}$ NRRL Y-7663 and NRRL Y-10,920 are sporogenous heterothallic diploids isolated from nature. The other strains are single-ascospore isolates derived from these diploids, as indicated. When grown alone, mating types showed neither conjugations nor ascospores.

${ }^{b}$ The frequency of conjugation and the number of apparently mature ascopores from intervarietal crosses were similar to the frequency and number from intravarietal crosses.

'The numbers in parentheses are percentages.

The ascospore walls of $I$. terricola show greater complexity than is evident in the walls of the other species of the genus (Fig. 12). A distinct inner layer is visible, and this becomes progressively more electron dense toward the surface. Surrounding this layer is an outer electron-dense mantle of wall material from which the protuberances arise. Each of the protuberances has an inner, less dense matrix.

FIG. 1. Scanning electron micrograph of an ascospore from I. occidentalis NRRL Y-7552.

FIG. 2. Transmission electron micrograph of an ascospore from I. occidentalis NRRL Y-7552.

FIG. 3. Scanning electron micrograph of ascospores from I. scutulata var. scutulata NRRL Y-7663.

FIG. 4. Transmission electron micrograph of ascospores from I. scutulata var. scutulata NRRL Y-7663.

FIG. 5. Scanning electron micrograph of ascospores from I. scutulata var. exigua NRRL Y-10,920.

FIG. 6. Transmission electron micrograph of ascospores from I. scutula var. exigua NRRL Y-10,920. 

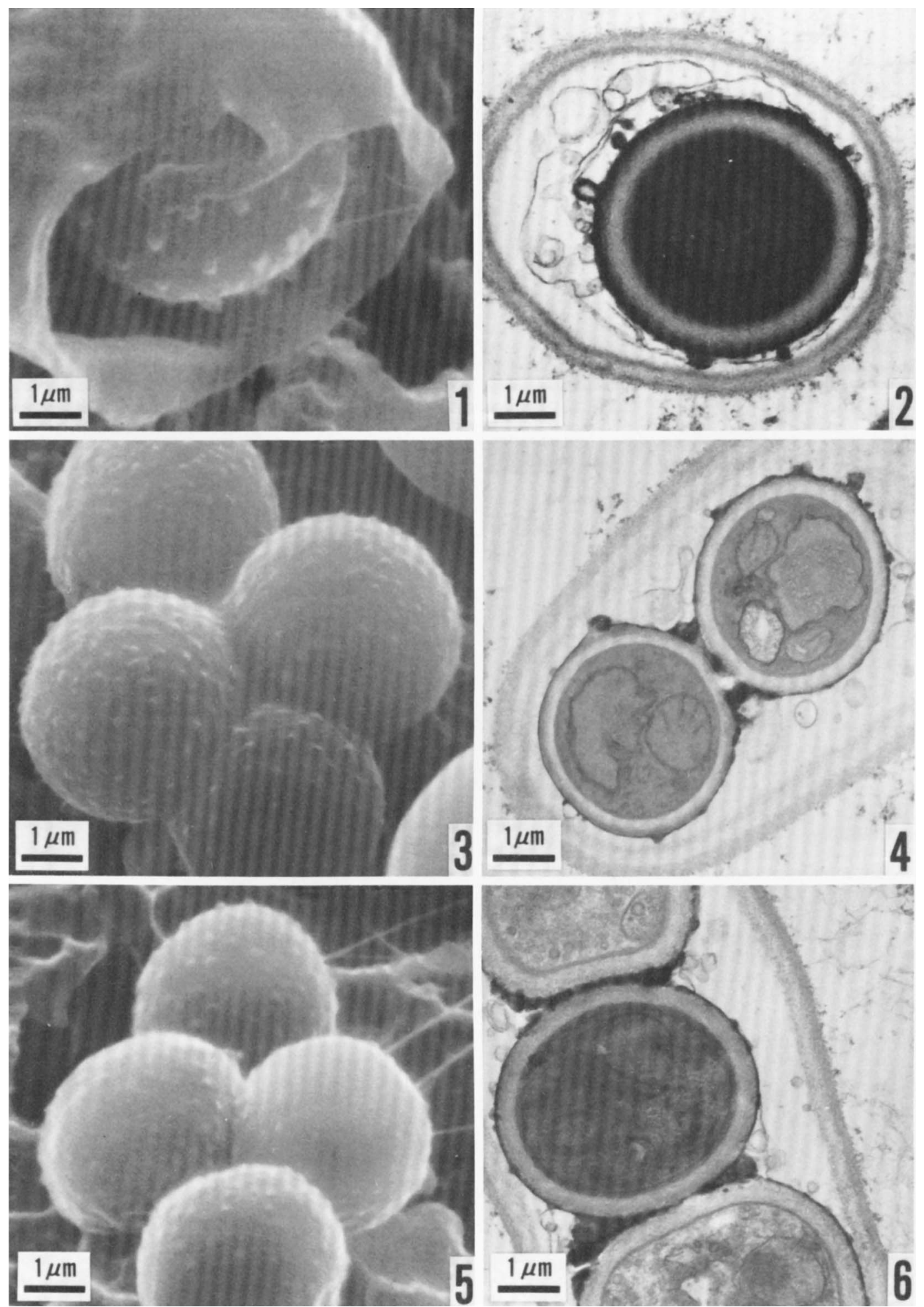


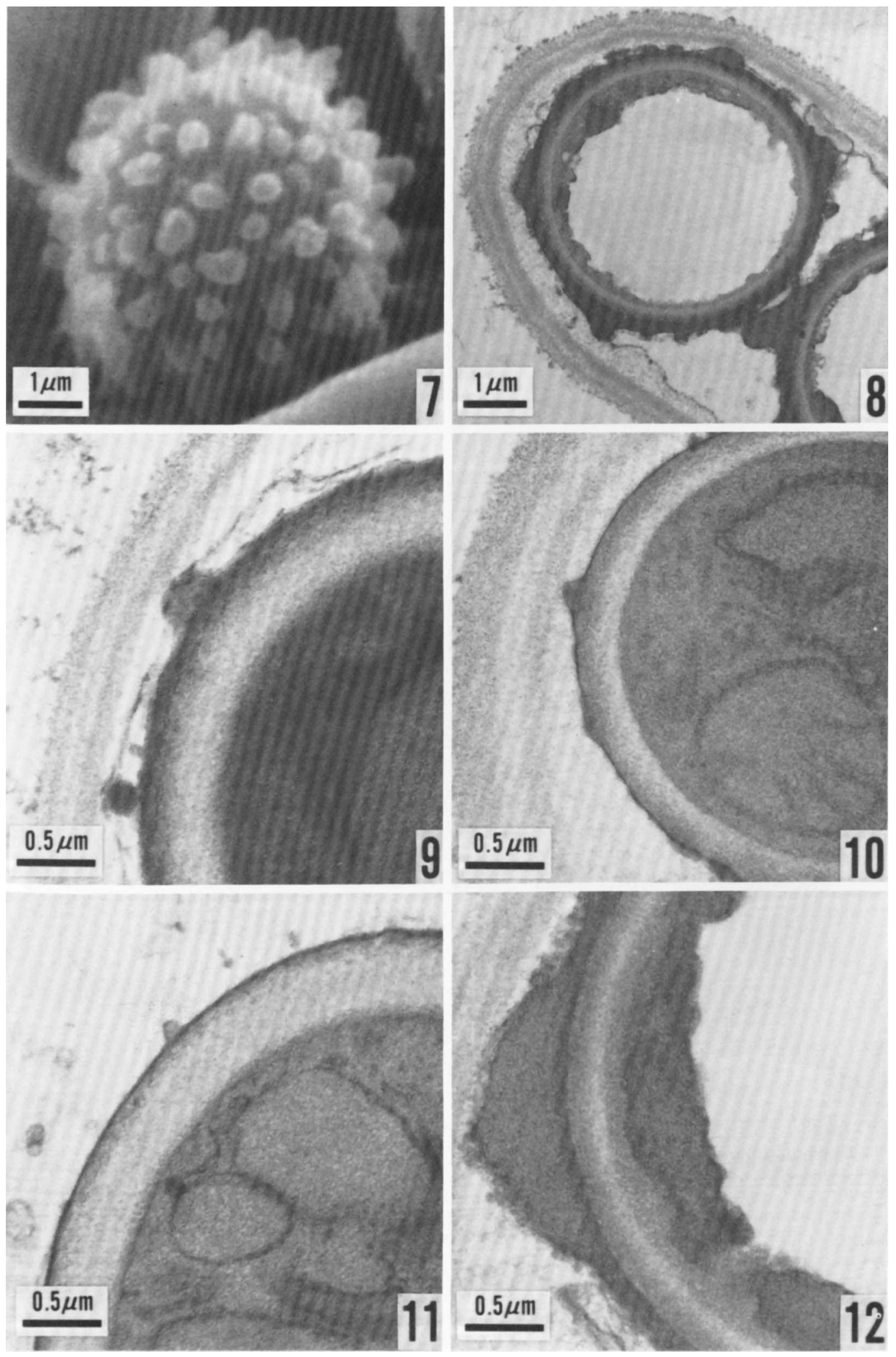




\section{DISCUSSION}

Ascospore ultrastructure has served as an indicator of relatedness among yeasts, and species with roughened spores are generally placed in genera separate from smooth-spored species $(7$, 8). Nitrate-negative species with roughened spheroidal ascospores have been assigned to $D e$ baryomyces, the Torulaspora section of Saccharomyces, and Pichia. Species of Debaryomyces form asci by parent-bud conjugation, and Kreger-van Rij and collaborators $(9,10,13)$ have shown the spore walls to be comprised of a thick, electron-light inner layer and a thin, electrondense outer layer. The surface ornamentation originates from the inner layer of the spore wall. Torulaspora species frequently have asci with a tapered protuberance. The ascospore ornamentation of this group also arises from the thick inner layer, but this layer is divided by a thin electron-dense ring not found in Debaryomyces spores. Those species of Pichia with roughened spheroidal spores, which we have transferred to Issatchenkia, form unconjugated asci, and the spore ornamentation, with the exception of that of I. scutulata var. scutulata, seems to arise from the outer spore wall. The most striking variation is shown by $I$. terricola, the spore wall of which shows additional layering that is quite distinctive.

Another characteristic of apparent phylogenetic significance is the structure of ubiquinone, or coenzyme $Q$, in the electron transport system. Species of Torulaspora produce Q-6 ubiquinone, whereas Debaryomyces and species of Pichia with round, smooth spores from Q-9 ubiquinone (36-39), in accord with differences in other molecular criteria (24). All species that we have assigned to Issatchenkia produce Q-7 ubiquinone. On the basis of ascospore surface ultrastructure, type of ascus, and chemical structure of the ubiquinone present, it appears that the species assigned to Issatchenkia represent a phylogenetically distinct group. The difference in spore wall layering exhibited by $I$. terricola, and to a lesser degree by $I$. scutulata var. scutulata, is interpreted as natural variation within the genus. This heterogeneity is in contrast to the uniformity of ascospore wall layering found in Debaryomyces and Torulaspora.

The surface topography and internal structure of ascospores from Saccharomyces telluris van der Walt resemble the topography and internal structure of the ascospores of the majority of Issatchenkia species (Kurtzman, unpublished data). Because little is known of the sequence of ascus formation by this species and because the species has a Q-6 ubiquinone system, it was not transferred to Issatchenkia.

We initially considered NRRL Y-7552 to be an atypical strain of $I$. orientalis that failed to utilize citric acid or to grow at $40^{\circ} \mathrm{C}$. However, it showed only 3 to $8 \%$ DNA base sequence complementarity with the other three strains of I. orientalis and clearly proved to be a member of a different species, $I$. occidentalis, which was previously demonstrated to represent the perfect form of $C$. sorbosa by mating tests (15); this relationship has been confirmed by DNA reassociation. Although neither $C$. krusei nor $C$. requinyii could be shown by mating tests to represent the imperfect form of $I$. orientalis, reassociation experiments verified conspecificity. These strains may be either asporogenous diploids or of the same mating type.

Assessment of relatedness among yeasts through comparison of DNA base sequence complementarity seems to offer a quantitative means for determining kinship that is superior to present taxonomic schemes, which can be influenced markedly by changes in a few genes, such as those controlling mating competence or carbon assimilation. Price et al. (24) suggested that with appropriate reannealing conditions, strains showing 80 to $100 \%$ DNA base sequence relatedness would almost certainly belong to the same species. Strains showing no more than 20 to $25 \%$ complementarity are generally considered to belong to different species $(1,16,19-21$, 24). In contrast to bacterial systems (4), values in the 20 to $80 \%$ range have been found only infrequently between yeasts, and their significance has yet to be assessed.

Recently, we reported $25 \%$ base sequence

FIG. 7. Scanning electron micrograph of an ascospore from a cross between I. terricola NRRL YB-4310 and NRRL Y-7549-25.

FIG. 8. Transmission electron micrograph of ascospores from a cross between I. terricola NRRL YB-4310 and NRRL Y-7549-25.

FIG. 9. Transmission electron micrograph of a portion of an ascospore wall from $I$. occidentalis NRRL Y7552.

FIg. 10. Transmission electron micrograph of a portion of an ascospore wall from I. scutulata var. scutulata NRRL Y-7663.

FIG. 11. Transmission electron micrograph of a portion of an ascospore wall from $I$. scutulata var. exigua NRRL Y-10,920.

FIG. 12. Transmission electron micrograph of a portion of an ascospore wall from a cross between $I$. terricola NRRL YB-4310 and NRRL Y-7549-25. 
complementarity between Pichia amylophila Kurtzman et al. and Pichia mississippiensis Kurtzman et al. (Kurtzman et al., in press). These heterothallic species were capable of interspecific mating, but none of the ascospores was viable. A more striking example is provided by $I$. scutulata var. scutulata and I. scutulata var. exigua. Base sequence complementarity between these two varieties averaged only $24 \%$ (Table 3), yet intervarietal matings gave 3 to $6 \%$ viable ascospores (Table 4). Sibling matings between cultures from these ascospores formed sporogenous cultures with increased ascospore viability (17\%). Backcrosses of these progeny to the mating types derived from the original diploids gave viable ascospores, and this suggested that the intervarietal progeny were not amphidiploids. Although we have retained the original varietal designations because of reduced fertility and low sequence complementarity between the varieties, these findings are of considerable importance to yeast taxonomy, for they show that strains capable of genetic exchange may exhibit DNA relatedness no greater than about $15 \%$ above the relatedness observed between unrelated species. Consequently, we must consider how our data influence the use of DNA studies for taxonomic work.

Determination of species boundaries can be made on the basis of a number of criteria, but ability to hybridize seems to be of cardinal importance. Dobzhansky (5) noted that among sexually reproducing and outbreeding organisms, species can be defined as Mendelian populations or arrays of populations that are reproductively isolated from other population arrays. We suggest that where hybridization can be used to determine speciation, not only must progeny from the initial crosses be viable, but furthermore, at least one additional generation of crosses should be made and these progeny should be tested for mating competence. Backcrosses can be used to detect amphidiploids. Because of the many factors affecting mating and subsequent development of the sexual spores, failure to mate or to form viable progeny may not mean lack of relatedness.

Given the relative recency of DNA reassociation studies, we have found little published work that examines DNA relatedness between species hybridizable to the $F_{2}$ generation. One example that is similar to our results concerns hybridization of the frogs Xenopus laevis and Xenopus borealis. Comparisons made by measuring the thermal stabilities of hybrid double-stranded DNAs from these two species gave a difference in thermal denaturation temperatures of $12^{\circ} \mathrm{C}$, which, extrapolating from studies of yeast DNA
(24), corresponds to approximately $20 \%$ base sequence complementarity $(6,35)$. By comparison, the extent of relatedness between the DNAs of humans and New World monkeys is somewhat greater (difference in thermal denaturation temperatures, $10^{\circ} \mathrm{C}$ ). Male hỷbrids of $X$. laevis by $X$. borealis are sterile, whereas the females form diploid eggs that can be fertilized to produce triploid progeny (6). Thus, fertile $F_{2}$ hybrids between these two sympatric species apparently do not occur. Allopatry seems to account for the genetic divergence between the two varieties of I. scutulata. Phaff et al. (23) isolated all strains of $I$. scutulata var. scutulata from the island of Hawaii; all strains of $I$. scutulata var. exigua were obtained from British Columbia, Canada, or the adjacent state of Washington. Both varieties were associated with slime fluxes, but the slime fluxes were on different tree species.

In view of the fertile $F_{2}$ progeny from crosses between $I$. scutulata var. scutulata and $I$. scu. tulata var. exigua, we have retained the two as varieties of the same species rather than as sibling species. Data from the intervarietal crosses suggest that continued interbreeding may increase genetic homology between the varieties, and we are presently investigating the effect that this has on base sequence complementarity.

Comparisons between other closely related taxa are needed before firm guidelines can be formulated concerning the extent of DNA relatedness that might be expected between yeast species. When current techniques are used, strains showing less than 10 to $15 \%$ DNA complementarity should probably be considered different species. The suggestion of Price et al. (24) that strains showing 80 to $100 \%$ DNA relatedness are almost certainly conspecific seems valid, and on the basis of our work, this range will probably need to be extended considerably. Although a nuisance to taxonomists, borderline cases, as exemplified by $I$. scutulata var. scutulata and I. scutulata var. exigua, may provide some insight into factors at the molecular level that direct speciation in simple eucaryotes.

\section{ACKNOWLEDGMEN'TS}

We are greatly indebted to Y. Yamada for providing coenzyme $\mathbf{Q}$ determinations for several of the Issatchenkia species, to C. W. Price for helpful discussions, to F. L. Baker for operation of the scanning electron microscope, and to $\mathrm{H}$. M. Howe for providing the Latin diagnosis of the new species.

\section{REPRINT REQUESTS}

Address reprint requests to: Dr. C. P. Kurtzman, Northern Regional Research Center, 1815 N. University St., Peoria, IL 61604 . 


\section{LITERATURE CITED}

1. Bak, A. L., and A. Stenderup. 1969. Deoxyribonucleic acid homology in yeasts. Genetic relatedness within the genus Candida. J. Gen. Microbiol. 59:21-30.

2. Bernardi, G., M. Faures, G. Piperno, and P. P. Slonimski. 1970. Mitochondrial DNAs from respiratory-sufficient and cytoplasmic respiratory-deficient mutants of yeast. J. Mol. Biol. 48:23-43.

3. Boidin, J., M. C. Pignal, and M. Besson. 1965. Le genre Pichia sensu lato. Quatriéme contribution. Bull. Soc. Mycol. Fr. 81:566-606.

4. Brenner, D. J. 1973. Deoxyribonucleic acid reassociation in the taxonomy of enteric bacteria. Int. J. Syst. Bacteriol. 23:298-307.

5. Dobzhansky, T. 1976. Organismic and molecular aspects of species formation, p. 95-105. In F. J. Ayala (ed.), Molecular evolution. Sinauer Associates, Inc., Sunderland, Mass.

6. Galau, G. A., M. E. Chamberlin, B. R. Hough, R. J. Britten, and E. H. Davidson. 1976. Evolution of repetitive and nonrepetitive DNA, p. 200-224. In F. J. Ayala (ed.), Molecular evolution. Sinauer Associates, Inc., Sunderland, Mass.

7. Kreger-van Rij, N. J. W. 1970. Debaryomyces Lodder et Kreger-van Rij nom. conserv., p. 129-156. In J. Lodder (ed.), The yeasts-a taxonomic study. North-Holland Publishing Co., Amsterdam.

8. Kreger-van Rij, N. J. W. 1970. Pichia Hansen, p. 455554. In J. Lodder (ed.), The yeasts-a taxonomic study. North-Holland Publishing Co., Amsterdam.

9. Kreger-van Rij, N. J. W., and M. Veenhuis. 1975. Electron microscopy of ascus formation in the yeast Debaryomyces hansenii. J. Gen. Microbiol. 89:256-264.

10. Kreger-van Rij, N. J. W., and M. Veenhuis. 1976. Ultrastructure of the ascospores of some species of the Torulaspora group. Antonie van Leeuwenhoek J. Microbiol. Serol. 42:445-455.

11. Kudriavzev, V. I. 1960. Die Systematik der Hefen. Akademie-Verlag. Berlin.

12. Kurtzman, C. P., F. L. Baker, and M. J. Smiley. 1974. Specimen holder to critical-point dry microorganisms for scanning electron microscopy. Appl. Microbiol. 28: 708-712.

13. Kurtzman, C. P., and N. J. W. Kreger-van Rij. 1976. Ultrastructure of ascospores from Debaryomyces melissophilus, a new taxonomic combination. Mycologia 68:422-425.

14. Kurtzman, C. P., and M. J. Smiley. 1974. A taxonomic re-evaluation of the round-spored species of Pichia, p. 231-232. In H. Klaushofer and U. B. Sleytr (ed.), Proceedings of the 4th International Symposium on Yeasts, Vienna, Austria. I. Hochschülerschaft an der Hochschule für Bodenkultur, Vienna.

15. Kurtzman, C. P., and M. J. Smiley. 1976. Heterothallism in Pichia kudriavzevii and Pichia terricola. Antonie van Leeuwenhoek J. Microbiol. Serol. 42:355-363.

16. Kurtzman, C. P., and M. J. Smiley. 1979. Taxonomy of Pichia carsonii and its synonyms Pichia vini and $P$. vini var. melibiosi: comparison by DNA reassociation. Mycologia 71:658-662.

17. Kurtzman, C. P., M. J. Smiley, and F. L. Baker. 1975. Scanning electron microscopy of ascospores of Debar. yomyces and Saccharomyces. Mycopathol. Mycol. Appl. 55:29-34.

18. Marmur, J. 1961. A procedure for the isolation of DNA from microorganisms. J. Mol. Biol. 3:208-218.

19. Mendonça-Hagler, L. C., and H. J. Phaff. 1975. Deoxyribonucleic acid base composition and DNA/DNA hybrid formation in psychrophobic and related yeasts. Int. J. Syst. Bacteriol. 25:222-229.

20. Meyer, S. A., K. Anderson, R. E. Brown, M. T. Smith, D. Yarrow, G. Mitchell, and D. G. Ahearn. 1975.
Physiological and DNA characterization of Candida maltosa, a hydrocarbon utilizing yeast. Arch. Microbiol. 104:225-231.

21. Meyer, S. A., R. E. Brown, and M. T. Smith. 1977. Species status of Hanseniaspora guilliermondii Pijper. Int. J. Syst. Bacteriol. 27:162-164.

22. Novák, E. K., and J. Zsolt. 1961. A new system proposed for yeasts. Acta Bot. Acad. Sci. Hung. 7:93-145.

23. Phaff, H. J., M. W. Miller, and M. Miranda. 1976. Pichia scutulata, a new species from tree exudates. Int. J. Syst. Bacteriol. 26:326-331.

24. Price, C. W., G. B. Fuson, and H. J. Phaff. 1978. Genome comparison in yeast systematics: delimitation of species within the genera Schwanniomyces, Saccharomyces, Debaryomyces, and Pichia. Microbiol. Rev. 42:161-193.

25. Schildkraut, C. L., J. Marmur, and P. Doty. 1962. Determination of the base composition of deoxyribonucleic acid from its buoyant density in $\mathrm{CsCl}$. J. Mol. Biol. 4:430-433.

26. Seidler, R. J., M. D. Knittel, and C. Brown. 1975. Potential pathogens in the environment. Cultural reactions and nucleic acid studies on Klebsiella pneumo niae from chemical and environmental sources. Appl. Microbiol. 29:819-825.

27. Seidler, R. J., and M. Mandel. 1971. Quantitative aspects of deoxyribonucleic acid renaturation: base composition, state of chromosome replication, and polynucleotide homologies. J. Bacteriol. 106:608-614.

28. Szép, E., and E. K. Novák. 1963. A new yeast species: Candida requinyii n. sp. Acta Bot. Acad. Sci. Hung. 9: 447-453.

29. Szybalski, W. 1968. Use of cesium sulfate for equilibrium density gradient centrifugation. Methods Enzymol. 12B:330-360.

30. van der Walt, J. P. 1957. Three new sporogenous yeasts from soil. Antonie van Leeuwenhoek J. Microbiol. Serol. 23:23-29.

31. van der Walt, J. P. 1970. Saccharomyces Meyen emend. Reess, p. 555-718. In J. Lodder (ed.), The yeasts-a taxonomic study. North-Holland Publishing Co., Amsterdam.

32. van Uden, N., and H. Buckley. 1970. Candida Berkhout, p. 893-1087. In J. Lodder (ed.), The yeasts-a taxonomic study. North-Holland Publishing Co., Amsterdam.

33. Wetmur, J. G., and N. Davidson. 1968. Kinetics of renaturation of DNA. J. Mol. Biol. 31:349-370.

34. Wickerham, L. J. 1951. Taxonomy of yeasts. U. S. Dept. Agric. Tech. Bull. 1029:1-56.

35. Wilson, A. C. 1976. Gene regulation in evolution, p. 225234. In F. J. Ayala (ed.), Molecular evolution. Sinauer Associates, Inc., Sunderland, Mass.

36. Yamada, Y., M. Arimoto, and K. Kondo. 1977. Coenzyme $\mathbf{Q}$ system in the classification of some ascosporogenous yeast genera in the families Saccharomycetaceae and Spermophthoraceae. Antonie van Leeuwenhoek J. Microbiol. Serol. 43:65-71.

37. Yamada, $Y$., and K. Kondo. 1972. Taxonomic significance of the coenzyme $Q$ system in yeasts and yeastlike fungi. II, p. 781-784. In G. Terui (ed.), Fermentation technology today, Proceedings of the 4th International Fermentation Symposium. Society of Fermentation Technology, Osaka, Japan.

38. Yamada, Y., M. Nojiri, M. Matsuyama, and K. Kondo. 1976. Coenzyme $Q$ system in the classification of the ascosporogenous yeast genera Debaryomyces, Saccharomyces, Kluyveromyces, and Endomycopsis. J. Gen. Appl. Microbiol. 22:325-339.

39. Yamada, Y., T. Okada, O. Ueshima, and K. Kondo. 1973. Coenzyme $Q$ system in the classification of the ascosporogenous yeast genera Hansenula and Pichia. J. Gen. Appl. Microbiol. 19:189-208. 